DOI: 10.24234/wisdom.v14i1.293

Roman BULAT,

Hafiza BAICHOROVA

\title{
PSYCHO-PEDAGOGICAL RESOURCES AND THE QUALITY OF PROFESSIONAL TRAINING OF STUDENTS
}

\begin{abstract}
The scientific search for intra-University potential to improve the quality of training of student is based on the improvement of the quality management system of vocational training. Further development is based not on private technical solutions, but on the reengineering of the management system aimed at activating the psychological and pedagogical resources of the University.

Keywords: educational activities of the University, the main professional educational programs, professional training, quality management system, adaptive organizational structures, the psychological and pedagogical resources of the University.

Introduction

In September 2003, Russia committed itself to implementing the standards and guidelines developed by the European Association for quality assurance in higher education (ENQA). In the subsequent period of introduction of quality management systems of vocational training in higher education institutions of the country (2004-2008), significant controversy was caused by the implementation of the principle of orientation to the "customer", which was associated with the historical "untouchability" of the University community. In the technical Sciences for decades, it was believed that only a teacher based on the analysis of scientific achievements is able to determine the content of education (Bulat, 2009 ; Zhilina \& Bulat 2009). As a result of this attitude, the head of the Department, which later turned out to be a graduate of the University, and even more so the student himself, in this aspect

was given a passive role of "recipient" of education.

Now it is already realized that quality growth is connected with the development of the ability of the educational organization to satisfy the available and expected requirements of "customers" of professional training of students. In modern conditions without orientation to the present and future (in 5 years) requests of the external environment, the University can no longer guarantee the demand for its graduates and, as a result, ensure its competitiveness (Bulat, 2015, pp. 137-143). Therefore, when predicting changes in the external environment and risk assessment when making management decisions can not be limited to the implementation of the requirements of the Federal state educational standards of higher education (GEF HE), and it is necessary to "anticipate" the dynamics of the needs of "customers" and strive for their fullest satisfaction.
\end{abstract}


In the history of professional training in order to strengthen the security of the state, the issue of forming the readiness of graduates for further professional activity has been constantly given increased attention (Shadrina \& Bulat, 2010, pp. 36-43). This is evidenced by the historically developed planning of distribution of graduates, collecting feedback about them, making adjustments to the content of education on the basis of monitoring comments, recommenda- tions and suggestions of "customers". However, awareness of the essence of changing the object of accreditation from universities to their main professional educational programs (MPEP) and the adoption of the Federal law of December 29, 2012, N 273-FZ "On Education in the Russian Federation"1 significantly influenced the perception of the concept of quality of professional training of graduates and approaches to its provision (Fig. 1).

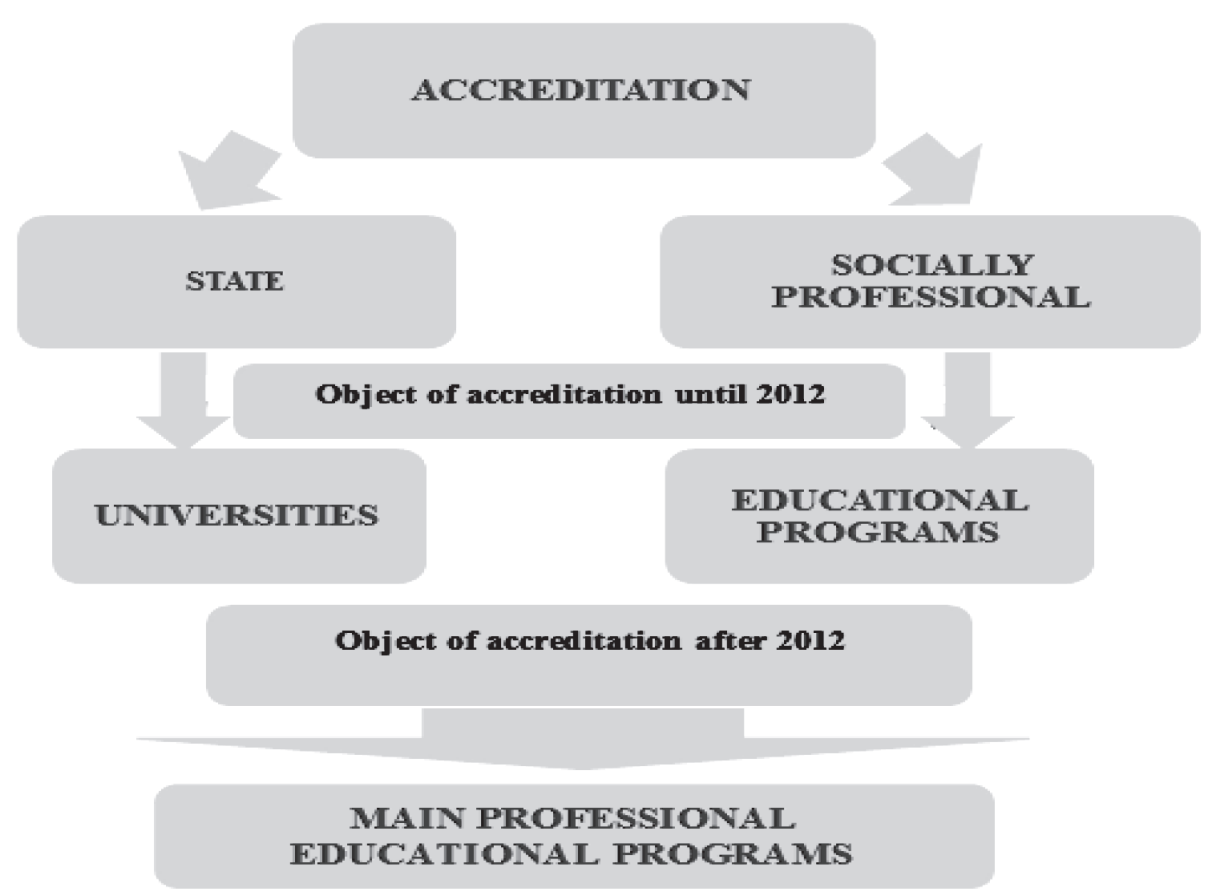

Fig. 1. Changes in State Approaches to the Examination of the Quality of Training.

Clarification of the goals and main activity of the University focused on the quality of training for each MPEP, leaving in the past the ability of universities to "replicate" higher education. The shift of emphasis from the educational activities of the University as a whole to the implementation of specific MPEP contributed to the development of an individual approach to each "customer" professional training of graduates. Such a "rejection of the principles of mass production" not only does not reduce but also incre- ases the demand for training (Caduca \& Bulat, 2013). In addition, it leads to significant savings of all types of University resources, eliminating the cost of achieving unclaimed results of training.

Moreover, the introduced changes contributed to the specification of requirements for gra-

\footnotetext{
See: Federal Law of 29 December 2012 N 273-FZ "On Education in the Russian Federation". Retrieved February 02, 2019 from: http://ivo.garant.ru/document?id=70191362\&sub $=0$.
} 
duates in each speciality and the growth of the responsibility of the University for the quality of their training. The achieved results were implemented in the implementation of updated GEF IN the third generation, including clarification of requirements for the quality of professional training of graduates and ensuring its diagnosability.

At the same time, in recent years, the shortcomings associated with such a negative factor in predicting changes in the external environment as the period of study at the University have become more apparent. Therefore, we see further improvement of quality in the University in the development of monitoring the requirements of “customers" for each specific MPEP.

\section{Methodological Framework}

A systematic approach to the management of vocational training at the University requires the coordination of all aspects of its activities (Milner, Evenko, \& Rapoport, 1983, pp. 225), including the systematization of the efforts of structural units (faculties, departments, educational and methodical departments, group of professional and psychological selection, research laboratory of training, personnel department, etc.). However, the lack of monitoring of goals, ways to achieve them and criteria for assessing the quality of professional training of graduates in various areas and specialities provokes the department to stagnate in the activities to improve it.

Therefore, at present, the emphasis should be shifted from the solution of private technological problems to further systematization of vocational training management aimed at activating the psychological and pedagogical resources of the University. At the same time, the quality management of education should be considered not as an end in itself, but as a means of forming the complete readiness of the graduate for professional activity.

Therefore, contrary to the experience of some universities, we have a critical attitude to the creation of a "parallel" quality management structure in addition to the University management system, which actually leads to the division of the management process into training management and quality management. We consider it as inexpedient to separate these processes, as well as separate creation on production and its quality. Therefore, our position is the need for measures to promote the reorientation of the goals of the existing University management substructures for the purposes of the quality management system of vocational training. One of the most appropriate solutions to this problem in practice, we believe the strengthening of the role of intraadaptive substructures of training management (see Meskon, Albert, \& Hedouri, 1992, p. 701).

Adaptive organizational structures are inherent in the revitalization of managers through the creation of new relationships between units and the flexible use of human resources of the organization. Therefore, we believe that in the existing conditions, the management resource of the quality growth of professional training in the University is to enhance the activities of such adaptive organizational structures as scientific and methodological sections on specialties and areas of training (hereinafter - the NMS on the SNP), United by the scientific and methodological Council of the University.

\section{Conducting Research and Some Results}

Our analysis showed that at present, not all departments, especially University-wide, in the development of training programs are aware of 
the goals of MPEP. As a result, the content of MPEP, which directly affects the formation of the required competencies of the graduate, does not take into account its purpose. In other words, the graduate's compliance with professional standards has been achieved only formally.

Analysis of the activities of the teaching staff showed that some teachers not only do not think about the dependence of the content of their classes on the specifics of a particular MPEP but also, entering the classroom, have a vague idea of the future speciality of students (Table 1). Moreover, some teachers are proud to note that the discipline they read with the same content as in the financial and economic or pedagogical University, where they teach part-time.

Table 1.

Analysis of Awareness of the Goals MPEP

Teaching Staff in the Process of its Organization

(Results of the Survey of the Teaching Staff)

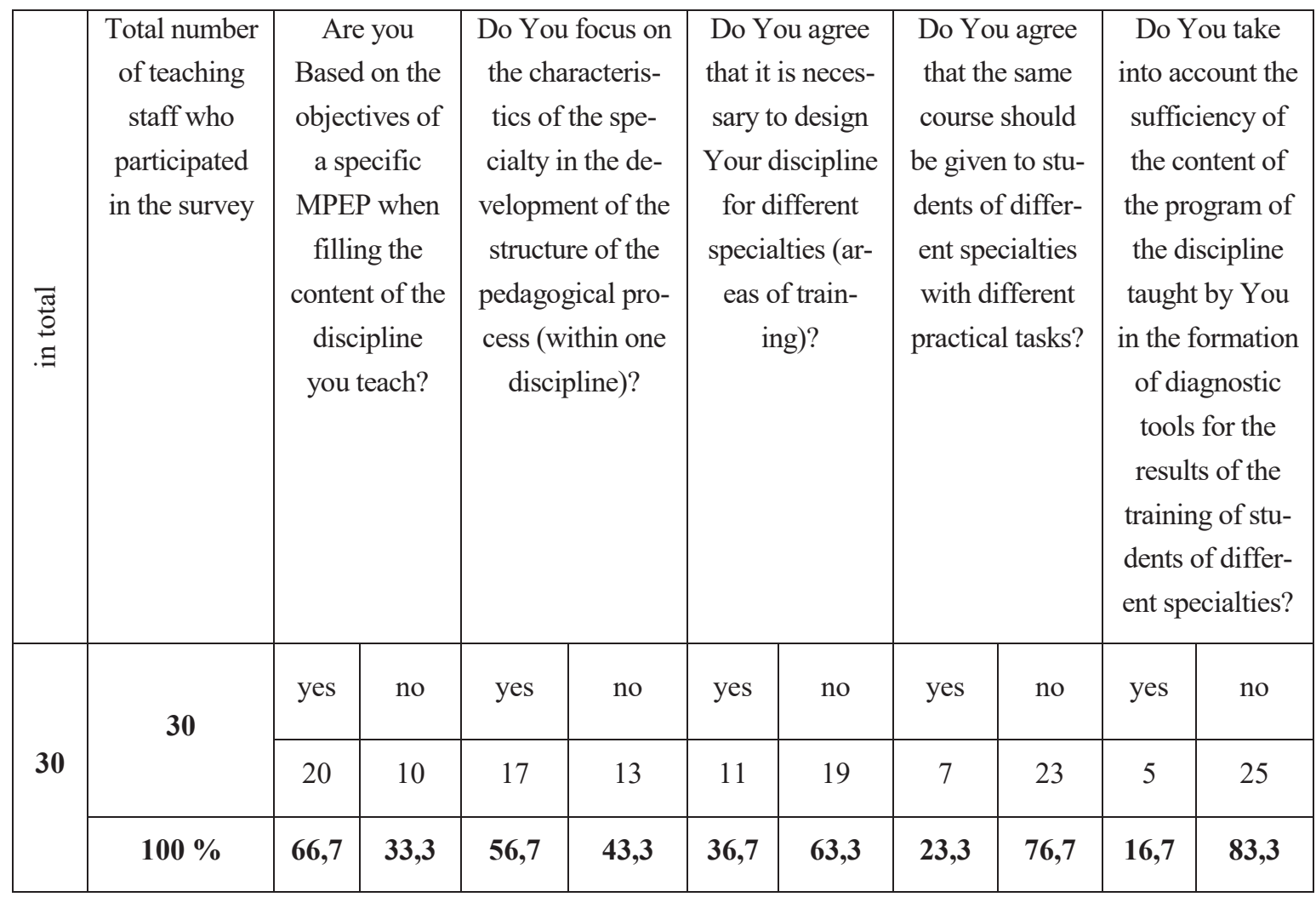

The strengthening of the role of NMS in the NSP is capable of compensating the abovementioned disadvantages due to the strengthening of horizontal relations (Milner, Evenko, \& Rapoport, 1983, p. 225) between departments. The intensification of the NMS activities on the
NSP ensures the development of common approaches to filling each discipline of all blocks with the corresponding goal of MPEP content, preventing its duplication in different disciplines, etc. In our opinion, it will allow not only to realize in practice requirements of legislative 
acts and other normative documents but also will provide the focus of all educational disciplines in each MPEP on the formation of readiness of the graduate to the solution of multidimensional tasks of further professional activity in the corresponding specialty.

The Chairman of the NMS on the NSP (one of the heads of departments) creates a creative team of like-minded people who are directly involved in the preparation of graduates in a particular specialty (MPEP). This supervisor becomes a subordinate, not a supervisor, but a supervisor inspiring subordinates in order to ensure the quality of professional training in the implementation of MPEP (Shadrina \& Bulat, 2010, pp. 35-40). In his competence - distribution within collective of tasks, functions and duties, and - from the moment of the organization of professional orientation work with potential entrants before modification of MPEP on the basis of monitoring of responses about graduates from "customers" of concrete military accounting specialty.

Such decisions can be in the field of both the volume and content of all academic disciplines of each Department, taking part in training in a particular specialty (Bespalko, 1989, p. 300). Decision-making at the NMS meetings on the NSP contributes to the awareness of each teacher of the goals of their activities for the implementation of MPEP.

For example, step-by-step consecutive hearing at the meetings of the NMS on the NSP of each teacher on the content and volume of the discipline taught by him within a particular specialty leads to the awareness of the teacher of his role in the results of the implementation of the MPEP by the University. Subsequent analysis and synthesis of the content and volume of each discipline allow the University to adjust the MPEP as a whole and to ensure the growth of the quality of training in a particular specialty.

As a result of such organization of activity simultaneously by all NMS on NSP of higher education institution, there are qualitative changes in all realized MPEP according to the purpose - readiness of the graduate for further professional activity on each specific specialty $(\mathrm{Bu}-$ lat, 2009 $)$.

Thus, the system of professional training can be qualitatively updated due to the emergence of new links between existing elements on the basis of the revitalization of adaptive organizational structures aimed at the implementation of the psychological and pedagogical potential of the University. This approach determines the effect of emergence, i.e. the acquisition of new properties by the system, which it did not previously possess, and hence the emergence of a new quality of training.

Awareness of the readiness of the graduate to further professional activity in the specialty as the goal of improving the quality of professional training at the University radically changes the perception of the teaching staff of the University system of management of vocational training, including a system of assessing the quality of education, monitoring the formation of readiness for professional activity, the system of motivation of the subjects of the educational process with a focus on the result of joint activities.

In General, the scheme of quality management of vocational training, activating the psychological and pedagogical resources of the University, is shown in Figure 2. 


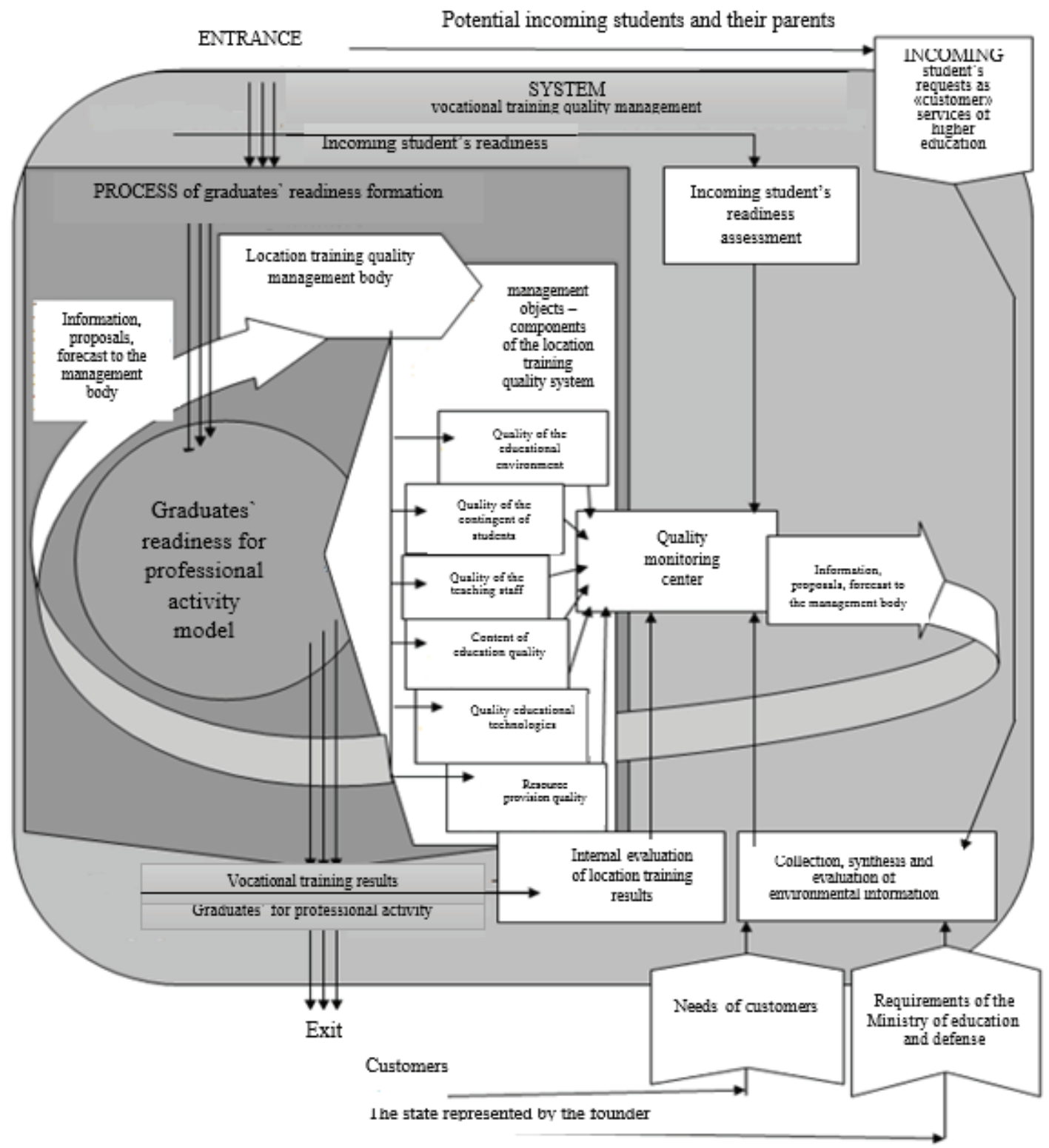

Fig. 2. General Scheme of the Quality Management System of Vocational Training.

The quality of professional training, as can be seen from the figure, consists of the quality of accepted students, the quality of the teaching staff, the quality of logistics and educational and laboratory equipment, the quality of educational technologies used, the quality of the educational environment of the University, the quality of the content of the main professional educational programs and many other factors. The result of quality management of vocational training is the compliance of the level of readiness of graduates to solve professional problems to the needs and demands of "customers" of vocational training and regulatory requirements of the Ministry of education of the Russian Federation.

At the same time, management decisions will be able to create an impulse for selforganization of personal structures of consciousness of teachers and students in the right direction only if they rely on forecasting changes in the external environment and multidimensional risk analysis. "Another error in evaluation, asso- 
ciated with insufficient objectivity, can lead to irreversible consequences in management decision-making" (Bespalko, 1989, p. 300). Therefore, management decisions should be made on the basis of objective and reliable information.

However, until now, some innovations, regardless of their effectiveness, are rejected because they threaten to reduce the "ringing" load with the resulting personnel reductions or require teachers to improve their skills, greater dedication and labour. As a result, management decisions can be made not by rational calculation of alternatives, but under the influence of subjective factors, and as a result - irrational factors can affect the fate of the organization as a whole. Excessive caution or risk-taking, increased ambition or passivity, the desire to make a career or escape responsibility - such motives may lie at the heart of strategic decisions (Burman, 2008, p. 260).

On the other hand, the University still maintains a system of quality control of education, characterized by the principle of "rejection". Such quality assurance in the production was not to improve it but to prevent the production of products that do not meet the established standards. This organization of the educational process belongs to the outgoing technological order. The traditional methods of control, used in the changed conditions and although convenient in many ways, are not effective enough yet.

With the aim of improving the quality of managerial decision-making requires the development and implementation of special procedures and technologies. Therefore, the importance of monitoring the quality of professional training of graduates is growing. The differences between the functions of this unit and the control are significant. Control as one of the functions of the management is aimed at organizing the implementation of the work plan, to solve the problem of determining the deviations of the actual results of management from the provided, has a situational nature and is short in time of implementation. In contrast to the control, monitoring is preceded by planning and decisionmaking and is associated with the functioning of the entire control system. This information support is based on regular monitoring of the state of the object of study, fixation or identification of problems and analysis of the results of management actions.

Monitoring is a systematic study of the elements of the quality of the training system, not an empirical collection of material. It is directed to the same objects, periodically repeats and thereby creates conditions for planning (annual, perspective, strategic). This analysis of information is aimed at studying the state system of quality of vocational training - from the position of conformity to the requirements of customers, the effectiveness of corrective actions and for forecasting possible changes in the external and internal environment to prepare proposals to the governing body.

It should be understood that traditionally used methods to identify the level of readiness of graduates for further professional activity in a particular specialty are not enough (Zvonnikov \& Chelyshkova, 2009, p. 272). The effectiveness of monitoring the quality of training depends on the dynamism and flexibility in adjusting the components of the quality assessment, depending on the transformation of the needs of the "customer", and on changes in the external environment as a whole (economic, political, etc.).

Therefore, a key component of monitoring the quality of training is a subsystem of analysis of the requirements of "customers" and their assessment of the level of readiness of graduates for professional activity. Therefore, the imperfec- 
tion of traditional forms of cooperation with "customers" predetermines changes, and as a result, the construction of a new system.

As part of this work, the analysis of collecting feedback on graduates carried out by the personnel department, as a whole, for the university should be transformed into a system of forecasting changes in the external environment based on the collection, compilation and evaluation of the information required to adjust each specific specialty separately.

Innovations in the work initiated by each Chairman of the scientific and methodological section for each specialty may include such previously unaffected sources of information collection as:

- questionnaire and survey the students of the faculty training and re-training (i.e. practising managers, current graduates);

- a questionnaire survey and a survey of graduates of previous years during traditionally organized meetings in 5-, 10-, 15anniversary, etc. of the University (i.e. practising managers, current graduates);

- centralized analysis of feedback from the heads of organizations on practical training and internships;

- target survey and survey of applicants, students and graduates (before graduation) of the University;

- questioning and questioning of teachers, employees and other categories of employees of the University.

Further comparison of the obtained data with the results of the internal evaluation of the quality of the readiness of graduates for professional activities will allow you to rapidly and comprehensively provide information for discussion at meetings of the NMS at the SNP with a view to developing the scientific-methodical
Council of the University to further control actions in all subsystems of the control system of the University.

\section{Conclusion}

Thus, the study of management resources of the quality of training of students showed that:

- now it is necessary to "foresee" dynamics of needs of "customers" and to aspire to their fullest satisfaction;

- the shift of emphasis from the educational activities of the University as a whole to the implementation of specific MPEP is aimed at saving the resources of the University, eliminating the cost of achieving unclaimed results of professional training;

- the growth of the quality of professional training should be based on significant changes not only in the technological subsystem of the system of professional training of the University but also in its other subsystems - pedagogical, organizational, economic, theoretical and methodological;

- contrary to the experience of some universities in creating a "parallel" quality management structure in addition to the University management system, further development is most rational due to the unification of the existing management system;

- reorientation of the objectives of the existing management structures to improve the quality of training is advisable on the basis of the revitalization of such intra-adaptive structures as scientific and methodological Council and scientific and methodological sections on specialties and areas of training;

- the activation of the NMS will ensure the growth of awareness of each teacher who takes part in the training of graduates, its 
role in achieving the goals of the Obor;

- management decisions will create an impulse for self-organization of personal structures of consciousness of teachers and students in the required direction only if they rely on forecasting changes in the external environment and risk analysis;

- for the purpose of the more exhaustive implementation of intra-University psychological and pedagogical resources, it is necessary to develop monitoring of the quality of professional training of cadets, which precedes planning and decision-making and is associated with the functioning of the entire management system;

- the emergence effect (acquisition of new properties by the quality management system of vocational training, which it did not have before) on the basis of reengineering of various links between the existing elements of the educational system of the University will raise the professional training of graduates to a new quality level.

\section{REFERENCES}

Bespalko, V. P. (1989). Slagaemye pedagogicheskoi tehnologii (Components of Pedagogical Technology, in Russian). Moscow: Pedagogy.

Bulat, R. E. $\left(2009^{\mathrm{a}}\right)$. Osobennosti upravleniya kachestvom voenno-tekhnicheskoi podgotovki specialistov (Features of Quality Management of Military-Technical Training, in Russian). People and Education, 2(19), 35-40.

Bulat, R. E. (2009 ). Problemy vnedrenija innovacij $v$ voenno-tehnicheskom obrazovanii (Problems of Innovation in MilitaryTechnical Education, in Russian). En- gineering Education, 5, 120-126.

Bulat, R. E. (2015). Kachestvo vysshego obrazovaniya $v$ vuze kak pedagogicheskaya sistema (The Quality of Higher Education at the University as a Pedagogical System, in Russian). Scientific and technical statements of St. Petersburg state Polytechnic University. Humanities and social Sciences, 4(232), 137143.

Burman, L. A. (2008). Upravlencheskie resheniya: uchebnik dlya vuzov (Management Decisions: Textbook for Universities, in Russian). Moscow: Delo.

Caduca, L. A., \& Bulat, P. E. (2013). Lichnostnoe razvitie obuchayushchikhsya kak cel' upravleniya kachestvom professional'nogo obrazovaniya (Personal Development of Students as the Goal of Quality Management of Professional Education, in Russian). Bulletin of Belgorod state University, 13(156), 238242.

Meskon, M. H., Albert, M., \& Hedouri, F. (1992). Osnovy menedzhmenta (Fundamentals of Management, in Russian). Moscow: Case.

Milner, B. Z., Evenko, L. I., \& Rapoport, S. V. (1983). Sistemnyi podkhod k organizacii upravleniya (System Approach to Management Organization, in Russian). Moscow: Economics.

Shadrina, E. Yu., \& Bulat, R. E. (2010). Aktual'nye voprosy upravleniya kachestvom lichnostno-orientirovannogo professional'nogo obrazovaniya (Actual Issues of Quality Management of PersonalityOriented Professional Education, in Russian). Engineering Education, 6, 36-43. 
Zhilina, A. I., \& Bulat R. E. (2009). Organizacionnyi aspekt upravleniya kachestvom voenno-professional'nogo obrazovaniya (Organizational Aspect of Quality Management of Military-Professional Education, in Russian). Kazan Pedagogical Journal, 3(69), 3-9.
Zvonnikov, V. I., \& Chelyshkova, M. B. (2009). Kontrol' kachestva obucheniya pri attestacii. Kompetentnostnyi podkhod (Control of Quality of Training at Certification. Competence Approach, in Russian). Moscow: Logos. 